Smoleńska Olga, Pilarska Marta. Health and functional benefits of yoga practice in times of the COVID-19 coronavirus pandemic. Pedagogy and Psychology of Sport. 2021;7(2):21-38. elSSN 2450-6605. DOI http://dx.doi.org/10.12775/PPS.2021.07.02.002 https://apcz.umk.pl/czasopisma/index.php/PPS/article/view/PPS.2021.07.02.002 https://zenodo.org/record/4717892

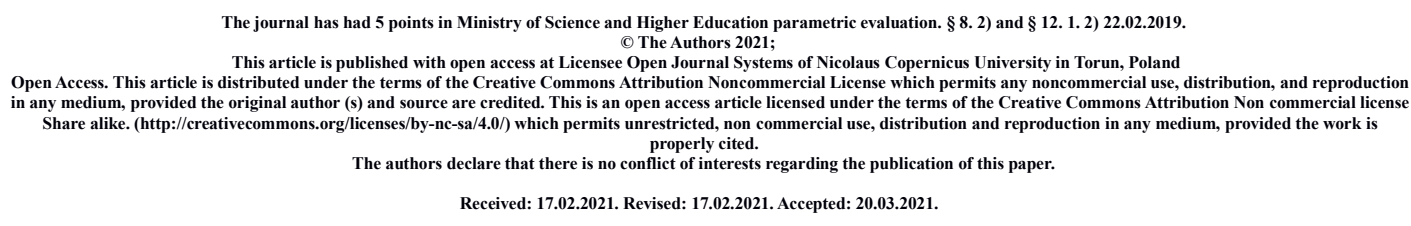

\title{
Health and functional benefits of yoga practice in times of the COVID-19 coronavirus pandemic
}

\author{
Olga Smoleńska, PhD, ORCID: https://orcid.org/0000-0002-2517-9081
}

Marta Pilarska, MA, ORCID: https://orcid.org/0000-0002-1284-0467

UMK Toruń, Faculty of Earth Sciences and Spatial Managment, Department Sport Science

\begin{abstract}
The purpose of this article is to identify and quantify the benefits of yoga practice, particularly in the most severe of the coronavirus pandemic and related lockdown periods. The subject of the research was the form and quality of online yoga practice, which has become an alternative to sports and stationary activities. The most important health benefits of yoga practice are also discussed. Using the method of analysis of documents and sources, the role and importance of yoga in the health context and its advantages related to maintaining health during the coronavirus pandemic have been demonstrated.

The authors of the publication also made an original quantitative and qualitative analysis of individual forms of online yoga practice, according to the most popular and used tools and technologies in this discipline. An analysis of functionalities conducted on Facebook and Instagram social networking sites, live broadcasts, applications that can be installed on smartphones and channels on the YouTube website, publishing videos for joint yoga practice, was developed. Using own observation and SWOT analysis, all the strengths and weaknesses of online yoga practice, as well as its opportunities and threats, were presented.
\end{abstract}

Key words: health, wellness, activity, yoga, pandemic, coronavirus, COVID-19

\section{Introduction}

The growing trend of a healthy lifestyle and taking care of your own physical and mental health meant that more and more people began to attend various types of classes offered by fitness clubs, gyms and wellness centers. One of the forms of activity that is increasingly appearing on the offer of such places is yoga. The situation in the world and the 
announcement of the global COVID-19 pandemic led to the fact that many such places were closed and people could only exercise at home. Yoga is such an undemanding form of activity that you can easily continue practicing it without leaving your home.

Yoga has been put on the intangible list by the UNESCO committee cultural heritage, in recognition of its study of Indian society, ranging from paths of health and medicine, to education and art. Yoga also has a lot health benefits. It helps in maintaining high posture and strengthens muscles, improves the work of the heart, improves the work of the respiratory system as well affects mental health. The psychological value of yoga is lowering stress level, turnover in the fleet with depression or anxiety. Thanks to meditation yoga helps people in their inner realization, leads to experiences of the state freedom and discover your nature. This form of activity is practiced not only by young people, but also mature people, regardless of gender or social position or professed religion.

\section{Health concept}

Health is a concept that is difficult to define and often ambiguously understood. „In colloquial language, health is very often defined as a normal state or the absence of disease or its symptoms" (Dolnośląski Szpital Specjalistyczny im. T. Marciniak Centrum Medycyny Ratunkowej/Emergency Medicine Center, http://www.szpitalmarciniak.wroclaw.pl/index.php? $\mathrm{c}=$ article $\& \mathrm{id}=9 \& \mathrm{pdf}=1$, access: 24.05 .2020$)$. However, this is a very general statement that says little. While „lack of disease or its symptoms" is not difficult to understand, defining ,normal state" may already be problematic. Therefore, the World Health Organization (WHO) formulated and included in 1948 a complete definition that states that ,health is a state of physical, mental and social well-being, not merely the absence of disease or disability" (Światowa Organizacja Zdrowia/WHO, https://www.who.int / about / who-we-are / constitution, access: 24.05.2020). WHO emphasizes that if you want to understand what health is, you should look at it much more broadly, because it is not only an antonym of disease but the mental state of a person, their relations with other people and the environment. From this definition it follows that health has three dimensions: physical, mental and social health, but now also spiritual health is distinguished. Taking into account the holistic or comprehensive concept of health, we can distinguish four of them. the following dimensions:

1. Physical health - proper functioning of the body and its systems and organs;

2. Mental health and health within it:

- mental - the ability to think clearly and logically,

- emotional health - the ability to recognize feelings and express them appropriately; ability to cope with stress, tension, depression and anxiety;

3. Social health - the ability to maintain proper relationships with other people and fulfill social roles;

4. Spiritual health - in some people it is related to religious beliefs and practices, in some it is related to maintaining inner peace (Woynarowska, Sokołowska 2000, p. 13).

This four-dimensional concept of health makes us realize that not only physical fitness determines our potential and level of vital energy. It refutes the biomedical definition of health which assumes that "the language of (bio) chemistry and (bio) physics is sufficient to explain the phenomena of health and disease" (Domaradzki 2013, p. 409). It should also take care of your mental health, social relations and the inner state of peace and balance to be able to fully enjoy your well-being.

How we understand health is closely related to how we care for it. In the 1970s, the then Minister of Health of Canada, Marc Lalonde, distinguished four factors influencing health (Instytut Profilaktyki Zdrowia/Institute of Health Prophylaxis, 
http://ipz.org.pl/uwwiedzowania-zdrowia/ access: 03.07.2020). In table (Tab.1) below its presented data defining the percentage value of the importance of a given determinant on shaping human health:

Tab. 1. Percentage the value of a determinant in shaping human health

\begin{tabular}{|c|c|}
\hline Determinants of health & Impact on health [\%] \\
\hline lifestyle & 50 \\
\hline genetic factors & 20 \\
\hline environment & 20 \\
\hline health care organization & 10 \\
\hline
\end{tabular}

Source: own study based on http://www.neurocentrum.pl/dcten/wp-content/uploads/markocka-maczka k5p.pdf, access: 25.06 .2020

The greatest influence on our health is the lifestyle understood as „diet, physical activity, the ability to cope with stressful situations, adequate sleep, the use of stimulants (nicotine, alcohol, psychoactive substances) or avoiding risk factors" (Główny Inspektor Sanitarny/Chief Sanitary Inspector, https://gis.gov.pl/zdrowie/co-to-jest-zdrowa-styl-zycia-iczemu-jest-wazny/ access: 24.05.2020).

\section{Purpose, problem and research hypotheses}

The main aim of the research was to establish and define the benefits of yoga practice, regarding especially in the past, the most severe in terms of restrictions, the period of the coronavirus pandemic and the related lockdown (forced stay in the place of residence). The subject is the form and quality of yoga practice online, which has become an alternative to sports and stationary activities. The specific objectives are to identify the most significant health benefits of yoga in general as well as to analyze the health benefits of quarantined physical activity, including yoga practice in particular. In detailing the research assumptions, it was assumed that an analysis of the various forms of practice should be conducted online according to the most popular and used tools and technologies in this discipline. The conducted research is of a supply nature and is mainly based on the yoga market in Poland.

The project focused on the analysis of the health benefits of yoga and its most important forms of practice online. 3 main practice paths were selected for the analysis online: 1. Live broadcasts, implemented using the main tools such as Facebook and Instagram.

2. Theme yoga applications for smartphones.

3. Movies and Internet channels, mainly on YouTube.

The research material of the work were mainly portals, tools and internet materials related to yoga. In addition, an analysis of literature and document sources was used to develop the theory.

The main problem in this research is: What benefits and in what form can yoga practice online bring in the era of the coronavirus pandemic? The resulting problems and detailed hypotheses are as follows:

P.1. What are the main health benefits of yoga for disease and the coronavirus?

H1. The main health benefits of yoga are relaxation and calming the mind, particularly beneficial in such a stressful period, as well as typical physiological activities that have a beneficial effect on the body.

P2. In what situations and to whom should yoga practice be addressed, including practice online during the coronavirus pandemic? 
H2. Yoga practice should be mainly directed towards the perio lockdown, due to the ease of its organization and small technical requirements, to senior groups that are highly exposed to loneliness or stress during this period.

P.3. What are the strengths and weaknesses and opportunity and threats of yoga practice online?

H3. The strengths of yoga online it is primarily its great variety, easy accessibility and free remote access. The weaknesses are the relatively small amount of live practice, low individuality and technological barriers. The opportunity is to expand the activities of yoga clubs with parallel or additional classes online. The threat is the development and return to other disciplines, slow dynamics, as well as progressing technological barriers.

\section{Research method}

The research method used for the research is the method of document and source analysis, used mainly to determine the role and importance of yoga in the health context. The main method used for the purposes of the study is qualitative and quantitive assesment and SWOT analysis used to investivigate advantages related to maintenance health and application in the fight against the coronavirus pandemic. In addition, the work was largely based on the netnographic method, examining mainly the materials and Internet sources that are the subject of research in this work, as well as own participant observation, resulting from own several years of yoga practice of both Authors.

\section{Health benefits of yoga practice during the COVID-19 pandemic}

Asanas yoga poses can be divided into several categories: standing, sitting, forward and backward bends, twists, inverted, lying and balance positions, and they all matter in the prevention and correction of body posture defects, especially in school-age children.Systematic exercise may lead to flattening of thoracic kyphosis and cervical lordosis (Grabara, Juszczyk, Szopa 2006). Other authors also describe studies on the effects of yoga on improving flexibility in students (Sereda et all 2020). Yoga also prevents diseases such as asthma or chronic bronchitis (YOGAMUDRA - Pracownia Jogi / Yoga Studio,https://yogamudra.pl/2015/06/24/wplyw-asan-jogi-yoga-asana/, acces: May 24, 2020). Thanks to breathing exercises, the circumference and capacity of the chest can be increased, which means that with one inhalation, more air gets into the chest, thus improving the breathing capacity of the body (Szopa 2000). In addition to its purely physical benefits, yoga also offers many psychological benefits. Like any physical activity, the practice of asanas improves your mood and introduces you to a state of well-being. By learning to calm down thoughts and a restless mind, you can be happier and live longer (Makvana 2016). Regular yoga practice improves coordination, reaction time, memory and even IQ (Francina 2007). Yoga is also thought to help in treating depressive symptoms. "Clinical depression is a lifethreatening medical condition, where the sadness and other symptoms can be so overwhelming that the person is disabled or even suicidal ". McCall (2007) found that yoga can help alleviate symptoms of depression and improve mood because it has been shown to be able to relieve tension and lower the cortisol levels that usually rise under stress.

During the COVID-19 pandemic, it is important to spot emotions as they arise, and to recognize and recognize the thoughts that trigger them. Keep in mind that these are often thoughts rather than facts, and many of them exaggerate the actual threat. Laszewska suggests using breathing and relaxation exercises, which are easily available on the Internet (UMK Toruń/Nicolaus Copernicus University in Toruń, https://www.umk.pl/wiadomosci/?id=26681, Access: 02.04.2020). One of the proposals for this type of activity is yoga, which is very often synonymous with a way to relax, including learning breathing techniques.

During a pandemic, it is important not to give in to stress or feelings of anxiety when 
people find themselves in extremely unique situations. Yoga has a positive effect on people suffering from anxiety and reduces the level of stress. All the anxiety associated with the epidemic can lead people who are less manageable with stress to depression. Yoga is recommended as an antidote in stressful situations. It is important to learn the ability to resist stress. Drela reports that, „under short-term stress, a slightly increased level of catecholamines and glucocorticoids increases the body's defenses, while when their concentrations exceed a certain critical value, they begin to inhibit the activity of defense cells. In chronic stress there is only an inhibitory effect" (Świat Nauki/Science World, https://www.swiatnauki.pl/8,488.html\#, access: 28.05.2020). The fact that a pathogen (virus, bacteria) enters the body does not necessarily mean that the infected will develop a disease. However, if the body of an infected person, especially the immune system, is weakened, e.g. due to stress, the entry of a virus or bacteria may be synonymous with the appearance of a disease. „In an experiment conducted at the Carnegie Mellon University's Laboratory for the Study of Stress, Immunity and Disease at Carnegie Mellon University in the United States, volunteers were injected into the nose with five different flu and cold viruses, and their stress levels and duration were measured beforehand. It turned out that the more and longer the subject was stressed, the higher the risk of contracting the virus and falling ill, and the longer the duration of the infection" (Synergiczni/Synergistic, https://synergiczni.pl/co-ma-stres-doodpornosci-czyli-jak-nasze-emocje-wplywaja-na-cialo, access: 28.05.2020). It's a good idea to take care of your mental health to avoid getting sick or reduce the risk of contracting the virus. Yoga improves the well-being and mood, which is worsened by the global situation caused by the declaration of the COVID-19 pandemic.

Breathing exercises can definitely help you learn to relax. In addition to the feeling of relaxation, they also bring many other benefits. Yoga practice, above all let's go, makes the vital capacity of the lungs increase, and the blood is better oxygenated, which improves the functioning of the immune system. Thanks to this, we can increase the efficiency of the lungs, but also prevent respiratory infections. It is important to take care of the good condition of the respiratory system, because the SARS-CoV-2 coronavirus, according to official information, can cause an acute infectious disease of this system.

Pranayama and and the sleigh they soothe and calm the mind, which leads to its increased sharpness and efficiency. Breathing through one nostril increases the activity of the opposite hemisphere of the brain (Przewodnik duchowy/Spiritual guide, https://przewodnikduchowy.pl/a/korzysci-plynace-z-uprawiania-jogi.php, access: $28 / 05 / 2020)$. It is worth taking care of improving concentration and acquiring the ability to focus, when during the pandemic many people were forced to work remotely. Working from home, there is a greater risk of distraction from the duties performed, because there are many stimuli that prevent you from gathering your thoughts and fully engaging in work. Yoga also increases the effectiveness of learning and increases the motivation to act (ibidem). It is significant when students are obliged to absorb a large amount of overdue material, or simply learn from home, at the computer. Chris Bailey writes that the average person who works in front of a computer is distracted by something every 40 seconds (Harvard Business Review Polska/Poland, https://www.hbrp.pl/b/jak-poprawic-koncentracji-i-byc-more-efektywnymlearn-four-strategies / PjUwg6OeF, access: 28.05.2020). Sometimes it is easy to restore concentration, but when something completely absorbs the attention of the person working in front of the monitor, it can take more than 20 minutes, according to research, to regain it. Bailey explains that the human brain's attention system is programmed to respond to anything that is pleasant, threatening, or new. People succumb to a novelty effect that causes their brain to be flooded with dopamine, a chemical pleasure trigger (ibidem), when they focus on something unknown.

Scientific research also proves that the positive and negative ions that occur in the 
atmosphere also have an impact on our health and well-being. „Individual air masses, participating in changing weather situations, are characterized by a different concentration of ions and different intensity of the electric field, which shows that the change of one mass of air to another entails changes in atmospheric electricity, and the impact of these changes in turn a living organism may be susceptible" (Kożuchowski 1998). Molecules that negatively affect the human body are cations, i.e. positive ions. "Positive ions secrete household appliances found in most homes. These are primarily TV sets, computers, microwave ovens, washing machines, dishwashers, electric cookers and refrigerators. Tobacco smoke and residential buildings also contribute to disturbing the ratio of positive and negative ions. The sources of negative ionization are heating devices, high-voltage networks, arrangement elements made of plastic, and even varnished floors" (Strefa Wolnej prasy/Free Press Zone, http://strefawolnejprasy.pl/chyszne-miec-dobre-samopoczucie-pomoga-w-tym-jony-ujemne/, access: 28.05.2020). Therefore, the more time a person spends at home, the more exposed he is to cations that have a negative impact on human health. „In the blood they cause an increase in serotonin content (which generates anxiety), as well as glucose, lactic acid and free fatty acids. The level of dopamine and norepinephrine increases in the brain, and thus also indirectly modifies the course of mental functions. Moreover, under their influence, the level of task performance deteriorates and the feeling of pessimism increases" (Kosmos/Cosmos, https://kosmos.ptpk.org/index.php/Kosmos/article/view/986/969, access: 28.05.2020). When forcibly spending most of our time at home, often mainly in front of the $\mathrm{TV}$, computer or phone in hand, it is worth trying to reduce the effects of negative ions and take up yoga practice, which reduces the feeling of anxiety, lowers stress levels, teaches better anger control and introduces positive mood.

The practice of yoga leads to a deeper understanding of your nature and an increase in self-awareness. When a pandemic situation is very stressful and makes people anxious, it is important to find inner peace. It is advisable not to leave the house, which means that people spend much more time with other household members. This can lead to more conflicts, so it is important to learn to be more patient and forgiving. All these features can be achieved, among others through yoga practice (Przewodnik duchowy/Spiritual guide, https://przewodnikduchowy.pl/a/korzysci-plynace-z-uprawiania-jogi.php, access: 28.05.2020).

Yoga can be practiced primarily without leaving home, alone, without any special requirements, equipment, clothes or additional costs. It is extremely easy nowadays because the Internet allows you to do exercises online. Many teachers or instructors conduct such classes through live broadcasts on their profiles on social media, e.g. on Instagram, Facebook or via webinars using e.g. the Zoom application. Yoga can also be practiced using applications installed on the phone or using the popular YouTube website. 


\section{Benefits of

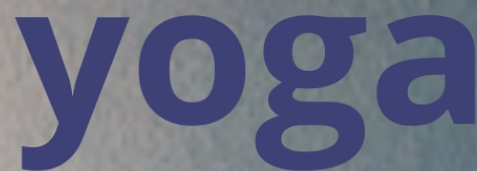

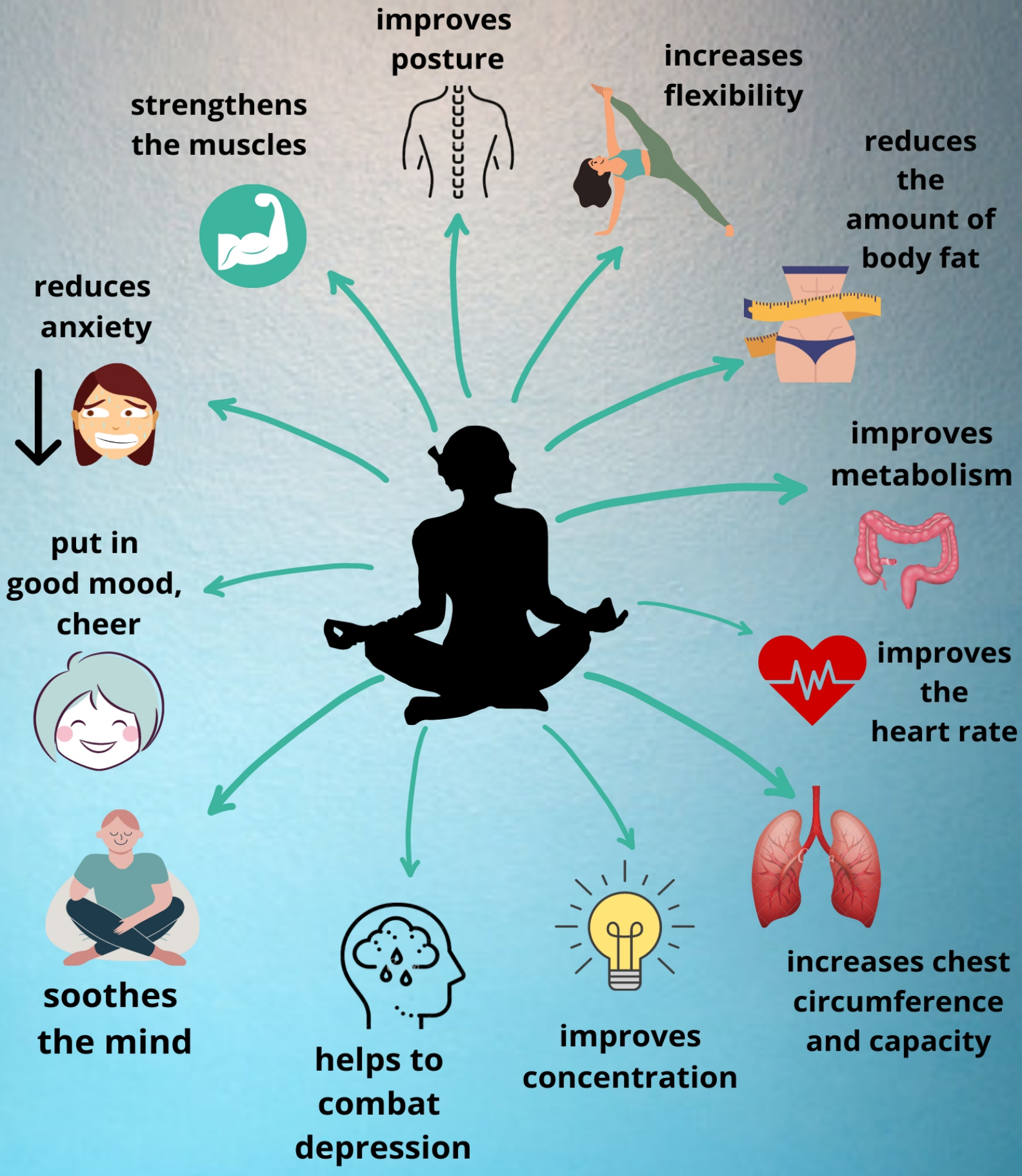

Fig. 1. Health benefits of yoga practice

Source: Own study using the website https://www.canva.com/, access: 11.07 .2020 


\section{Own research results - analysis of contemporary forms of yoga online practice during the pandemic COVID-19}

\section{Live broadcasts on social networks: Facebook and Instagram}

One of the modern forms of practicing yoga are classes conducted by teachers, yoga instructors, yoga houses (centers) or larger companies that run such lessons through various social networks. This is done via live broadcasts. This form of classes can be conducted, among others, on Facebook and Instagram. To take part in such classes, you should start by finding websites, fanpages of yoga schools that have added paid live streaming ${ }^{l}$ or offer free internships.

It's possibile to practice on Facebook by taking part in a live broadcast conducted by the given fanpage. It usually takes place on a specific day or days of the week at a fixed time. In order to disseminate information and encourage as many people as possible to participate in the practice, yoga schools are on their own fanpages create and share events. Events is a feature that allows you to organize meetings and respond to meeting invitations in the real world with people from Facebook. It specifies the date and time of the meeting, and anyone can participate if defined as public. Facebook in its function also allows you to invite people who are in the group of friends, and they are their friends. Therefore, in this way, the event can quickly gain popularity and bring many people to practice together. A big advantage of this type of activities is that they are free, so everyone can take part in them. Usually, these classes are held periodically, e.g. every Tuesday at 11:00, which makes it easy to maintain regular practice. It is possible to savel ives, thanks to which people who cannot appear in the class at a specific time will be able to return to the video and watch it later. Another advantage is that the social networking site in question notifies you of upcoming events, which will be useful for people who have no memory of such things, but still want to appear at meetings. These types of live internships offer, among others: Yoga Retreatment, YogaRepublic.pl and Yoga at the Source.

The photo social networking site Instagram has also been able to broadcast live since 2017. As in the previous case, the first step should be to find profiles on topics of interest to a given person and observe them. When a profile starts broadcasting, the follower receives a notification and can then join the joint exercises. The yogis on their profiles tell you when to expect live. Apart from the fact that they encourage practice by organizing free meditations, browsing their profiles can motivate you to practice persistently in order to perform complicated asanas in the future, but you can also get inspired, for example, by their way of being. Live streams on Instagram from May 14, 2020 cannot be saved by profile managers, which is a downside to the option that Facebook offers. For example, active yogis on Instagram who offer joint activities or meditation alone are: magdalena_yoga, Alo Yoga, yogahome.pl, maria_prokop_yoga.

The table below (Tab. 2) presents an analysis of the functionality of live broadcasts on Facebook and Instagram:

\footnotetext{
${ }^{1}$ live streaming - live classes that allow you to connect with your audience in real time.
} 
Tab. 2. Evaluation of the functionality of live broadcasts on Facebook and Instagram

\begin{tabular}{|c|c|c|c|}
\hline TESTED FEATURE & $\begin{array}{c}\text { RATING +/- } \\
\text { (possibility } \\
\text { or lack thereof) }\end{array}$ & INTERPRETATION & SCORING \\
\hline 1. Payment & - & $\begin{array}{l}\text { No payment, access } \\
\text { free }\end{array}$ & 1 \\
\hline $\begin{array}{l}\text { 2. Live exercises } \\
\text { with a coach }\end{array}$ & + & $\begin{array}{l}\text { Brak możliwości } \\
\text { ćwiczeń na żywo, } \\
\text { raczej } \\
\text { filmy }\end{array}$ & 1 \\
\hline $\begin{array}{l}\text { 3. Possibility } \\
\text { repeat the session }\end{array}$ & - & $\begin{array}{l}\text { No possibility of multiple } \\
\text { play and repeat }\end{array}$ & 0 \\
\hline $\begin{array}{l}\text { 4. Possibility } \\
\text { independent exercises }\end{array}$ & - & $\begin{array}{l}\text { Classes are conducted by } \\
\text { trainer }\end{array}$ & 0 \\
\hline $\begin{array}{l}\text { 5. High level } \\
\text { sessions and exercises, } \\
\text { adjusted to } \\
\text { individual } \\
\text { needs }\end{array}$ & - & $\begin{array}{l}\text { No individualisation, } \\
\text { rather } \\
\text { standard sessions they } \\
\text { will be } \\
\text { answer all } \\
\text { live participants }\end{array}$ & 0 \\
\hline $\begin{array}{l}\text { 6. Famous and } \\
\text { respected coaches }\end{array}$ & + & $\begin{array}{l}\text { Broadcasts are conducted } \\
\text { by trained, famous } \\
\text { or yoga school instructors } \\
\text { yoga teachers }\end{array}$ & 1 \\
\hline $\begin{array}{l}\text { 7. Alternative for } \\
\text { classes in clubs }\end{array}$ & + & $\begin{array}{l}\text { Most of the clubs were } \\
\text { running } \\
\text { only classroom classes, } \\
\text { no } \\
\text { conducts regular sessions } \\
\text { and } \\
\text { classes by schedule }\end{array}$ & 0 \\
\hline $\begin{array}{l}\text { 8. Ease of use } \\
\text { and access, interface } \\
\text { user }\end{array}$ & - & $\begin{array}{l}\text { Broadcasts only available } \\
\text { to } \\
\text { people with accounts on } \\
\text { social media data and } \\
\text { followers of profiles } \\
\text { leading live }\end{array}$ & 0 \\
\hline $\begin{array}{l}\text { 9. The visual side } \\
\text { session and general } \\
\text { appearance }\end{array}$ & + & $\begin{array}{l}\text { Variety of sessions, } \\
\text { practice } \\
\text { it's live so it is } \\
\text { carried on every time } \\
\text { in a different way }\end{array}$ & 1 \\
\hline $\begin{array}{l}\text { 10. Distribution i } \\
\text { promotion for people } \\
\text { exposed to } \\
\text { coronovirus (e.g. } \\
\text { seniors) }\end{array}$ & - & $\begin{array}{l}\text { Rather low popularity } \\
\text { transmission among } \\
\text { seniors, with } \\
\text { for keeping them } \\
\text { on portals that seniors } \\
\text { they usually don't }\end{array}$ & 0 \\
\hline Overall assessment & \multicolumn{2}{|l|}{ Total points: } & 4 \\
\hline
\end{tabular}

Source: Own study

\section{Smartphone applications}

There are many applications for yoga practice that can be installed on your smartphone. In the resources of the online store Google, when you search for „yoga practice”, there are items 250 (Google Play, https:/play.google.com/store/search?q=praktyka\%20jogi\&c=apps\&gl=PL, access: 28.05.2020). Several of them, although related to yoga, are not directly relevant to their 
practice. These are applications with music for meditation, bringing together people willing to share their experience and talk about yoga-related topics, or those that allow us to track our habits, such as the length of sleep, the amount of water drunk during the day, etc. The best rated, free applications that are designed to allow the user to take classes on their own, rated 4.9, 4.8 or 4.7 on a 5-point scale are: Yoga for Beginners | Down Dog, Yoga | Down Dog, Yoga - Track Yoga, Yoga for Beginners - Yoga Poses For Beginners, Daily Mudras (Yoga) For Your Healthy Life, Yoga tools from Sadhguru, Keep Yoga - Yoga \& Meditation, Daily Yoga - Yoga Fitness Plans. They are listed in the table below (Tab. 3):

Tab. 3. Applications for yoga practice on a smartphone

\begin{tabular}{|c|c|c|}
\hline APP NAME & $\begin{array}{c}\text { LOGO OF THE APPLICATION } \\
\text { AND THE NUMBER OF } \\
\text { OPINIONS }\end{array}$ & RATING \\
\hline $\begin{array}{l}\text { Yoga for Beginners } \\
\text { Down Dog }\end{array}$ & $($ St) & 4.9 \\
\hline Yoga | Down Dog & Yoga | Down Dog & 4.9 \\
\hline Yoga - Track Yoga & $\begin{array}{l}\text { Yoga-Track Yoga } \\
\text { ances }\end{array}$ & 4.8 \\
\hline $\begin{array}{l}\text { Yoga for Beginners - } \\
\text { Yoga Poses For } \\
\text { Beginners }\end{array}$ & 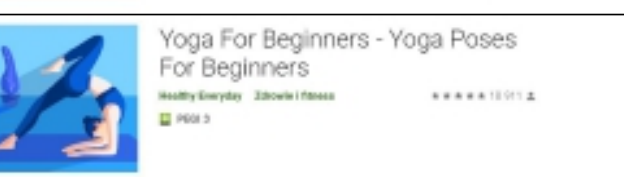 & 4.8 \\
\hline $\begin{array}{l}\text { Daily Mudras } \\
\text { (Yoga) - For Your } \\
\text { Healthy Life }\end{array}$ & 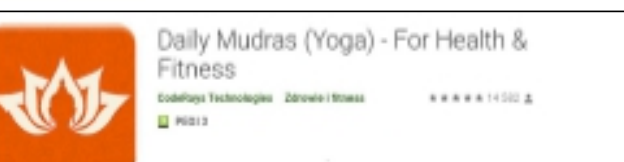 & 4.8 \\
\hline $\begin{array}{l}\text { Yoga tools from } \\
\text { Sadhguru }\end{array}$ & 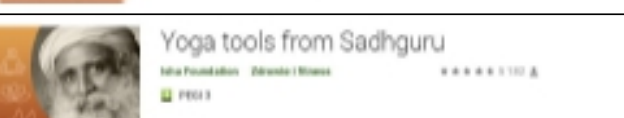 & 4.7 \\
\hline $\begin{array}{l}\text { Keep Yoga - Yoga } \\
\& \text { Meditation }\end{array}$ & $\begin{array}{l}\text { Keep Yoga - Yoga \& Meditation, } \\
\text { Yoga Dally Fitness } \\
\text { a nor }\end{array}$ & 4.7 \\
\hline $\begin{array}{l}\text { Daily Yoga - Yoga } \\
\text { Fitness Plans }\end{array}$ & 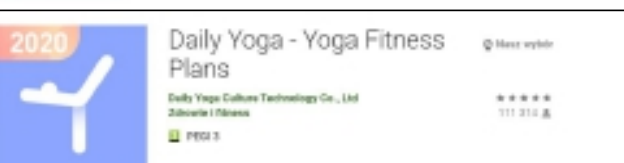 & 4.7 \\
\hline
\end{tabular}

Source: Own study based on https://play.google.com/store/apps, access: 09.07.2020

Most of the applications have over 1 million downloads, which proves their popularity and quality. The software listed in the table is written in English, which is a downside for Polish recipients who do not speak this language. The functionality of these applications is presented in the table (Tab. 4): 
Tab. 4. Evaluation of the functionality of the application for yoga practice

\begin{tabular}{|c|c|c|c|}
\hline TESTED FEATURE & $\begin{array}{c}\text { RATING +/- } \\
\text { (possibility } \\
\text { or lack thereof) }\end{array}$ & INTERPRETATION & SCORING \\
\hline 1. Payment & $+/-$ & $\begin{array}{l}\text { There are paid } \\
\text { applications, } \\
\text { but are also available } \\
\text { free }\end{array}$ & 1 \\
\hline $\begin{array}{l}\text { 2. Live exercises } \\
\text { with a coach }\end{array}$ & - & $\begin{array}{l}\text { No possibility to exercise } \\
\text { on } \\
\text { live, exercises } \\
\text { yourself by following } \\
\text { application instructions }\end{array}$ & 0 \\
\hline $\begin{array}{l}\text { 3. Possibility } \\
\text { repeat the session }\end{array}$ & + & $\begin{array}{l}\text { The possibility of using } \\
\text { application at any time } \\
\text { moment and many times }\end{array}$ & 1 \\
\hline $\begin{array}{l}\text { 4. Possibility } \\
\text { independent exercises }\end{array}$ & + & $\begin{array}{l}\text { Possibility to work } \\
\text { without a trainer }\end{array}$ & 1 \\
\hline $\begin{array}{l}\text { 5. High level } \\
\text { sessions and exercises, } \\
\text { adjusted to } \\
\text { individual } \\
\text { needs }\end{array}$ & + & $\begin{array}{l}\text { High individualisation, } \\
\text { thematic sessions and } \\
\text { programs }\end{array}$ & 1 \\
\hline $\begin{array}{l}\text { 6. Famous and } \\
\text { respected coaches }\end{array}$ & - & $\begin{array}{l}\text { Few coaches, especially } \\
\text { in } \\
\text { Poland has such } \\
\text { programs and } \\
\text { applications }\end{array}$ & 0 \\
\hline $\begin{array}{l}\text { 7. Alternative for } \\
\text { classes in clubs }\end{array}$ & + & $\begin{array}{l}\text { Most clubs } \\
\text { only conducted classes } \\
\text { stationary, does not drive } \\
\text { applications and } \\
\text { programs } \\
\text { parallel }\end{array}$ & 0 \\
\hline $\begin{array}{l}\text { 8. Ease of use } \\
\text { and access, interface } \\
\text { user }\end{array}$ & - & $\begin{array}{l}\text { Access to } \\
\text { Internet rather good } \\
\text { smartphone and high } \\
\text { level } \\
\text { handling }\end{array}$ & 0 \\
\hline $\begin{array}{l}\text { 9. The visual side } \\
\text { session and general } \\
\text { appearance }\end{array}$ & + & $\begin{array}{l}\text { Varied sessions and } \\
\text { programs, lots of awards } \\
\text { and } \\
\text { special visualizations }\end{array}$ & 1 \\
\hline $\begin{array}{l}\text { 10. Distribution } \mathrm{i} \\
\text { promotion for people } \\
\text { exposed to } \\
\text { coronovirus (e.g. } \\
\text { seniors) }\end{array}$ & - & $\begin{array}{l}\text { Very low popularity } \\
\text { application among } \\
\text { seniors, } \\
\text { uncomfortable practice on } \\
\text { small device }\end{array}$ & 0 \\
\hline Overall assessment & \multicolumn{2}{|l|}{ Total points: } & 5 \\
\hline
\end{tabular}

Source: Own study

\section{YouTube}

Practicing yoga is also possible on the YouTube website, established in 2005, where videos on various topics are posted. Recordings that will be sent by the author remain on the website until it is removed, so you can return to them many times, without any restrictions. Yoga channels publish videos of all kinds of sessions. These can be different types of yoga, exercises designed for people with specific ailments, or activities that help you reach your 
goal. Thanks to the variety of internships on offer, everyone can find something for themselves. The big advantage of this platform is that in addition to being able to hear the practitioner's voice, instructions and prompts, you can also observe the movements and thus have less doubts about the correctness of the asanas.

One of the Polish yogis on YouTube is Natalia Knopek, the founder of the channel simplife.pl, certified teacher in the Yoga Alliance standard, instructor of physical recreation with a specialization hatha yoga. In a short description of his channel, he writes: „I define my practice as dynamic, with simultaneous awareness of mind and body awareness in yoga. I also focus on effective relaxation, calming down and loosening - so useful in the present Word" (YouTube, $\quad$ https://www.youtube.com/channel/UCw-HC1NizWhlcFy7UT0kGcQ/about, access: 28.05.2020). Among her videos you can find morning yoga, good sleep yoga, digestive yoga, energizing yoga, lumbar yoga, chest opening yoga, wrist yoga, hip opening and sun salutation. Most of them last from 20 to 30 minutes, which is rather time that everyone can find during the day. The YouTube Knopek practice is intended especially for beginners or less advanced. Thanks to her clear statements and clear commands, these people can feel her support and perform the movements correctly, despite the lack of experience.

Fig. 2. The simplife.pl channel profile on YouTube

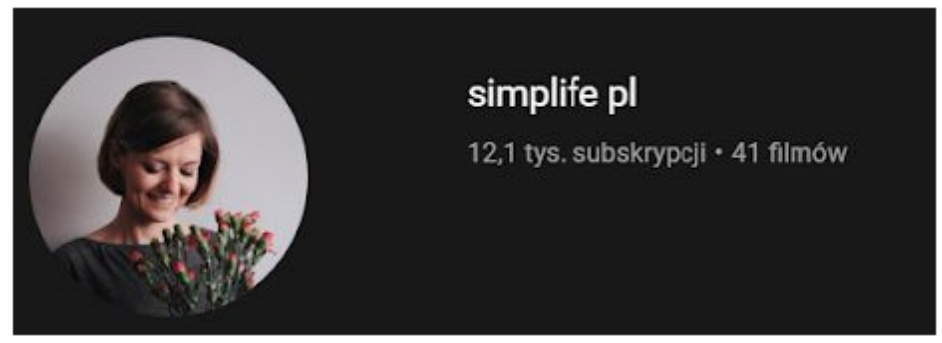

Source: https://www.youtube.com/, access: 09.07.2020

Another famous yogi is Barbara Tworek from the canal basiatworek.pl. She believes that |yoga is not only exercise - it is a way of discovering yourself on and off the mat. It is learning to rely on yourself, be honest, overcome your limits and accept what cannot be changed" (YouTube, https://www.youtube.com/channel/UCpqYY3zU3PbEPZ 7PwoiAw/about, access: 28.05.2020). Tworek runs her own website in the form of a blog, and in 2017, she decided to set up a channel on YouTube and then published her first video. Starting with introducing her viewers to yoga, talking about what it is and giving some beginners' advice, then she began publishing yoga practice videos, which include: yoga for runners, yoga for strong $\operatorname{core}^{2}$ for lively legs, for the lower back, for heavy legs, for stiff hips, and some meditation videos. Tworek also in his films explains exactly every change of position, which allows you to feel like you are practicing with a real instructor. Most of the films last from a few to several minutes, so they can be used by people who do not have a lot of free time. For those who have more, it is possible to select multiple videos and personalize your practice, for example combining hip stiffness practice with lower back exercises.

\footnotetext{
${ }^{2}$ core - understood as deep muscle training; muscles of the hips, loins and abdomen, which are responsible for
} stabilizing the spine and pelvis 


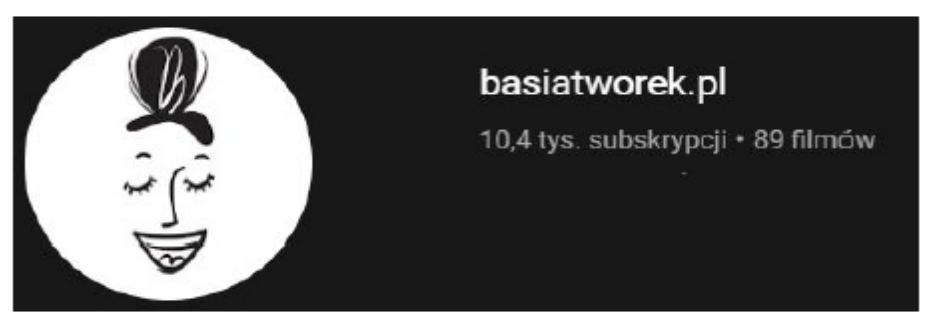

Fig. 3. Basiatworek.pl channel profile on YouTube

Source: https://www.youtube.com/, access: 09.07.2020

Małgorzata Mostowska is by far the most popular yoga teacher on YouTube, with around 230,000 subscribers. In the description of his channel, he writes, directing the words to his viewers: „I want to encourage you not only to practice yoga together, but also to introduce healthy habits into your daily routine. In other words: I will encourage you to a healthy life" (YouTube, https://www.youtube.com/user/kasieklxk/about, access: 28.05.2020). The films last from several to several dozen minutes, and among them we can find: yoga for a healthy spine, meditation for stress, calming yoga, yoga for seniors, yoga at the desk, facial yoga, breathing practice, yoga for pregnant women, yoga for strong back, slender thighs and much more. In addition to the projected image, where Mostowska conducts a yoga practice, the voice in the background describes the individual changes in position and suggests how to work with the breath.

Fig. 4. Małgorzata Mostowska's channel profile on YouTube

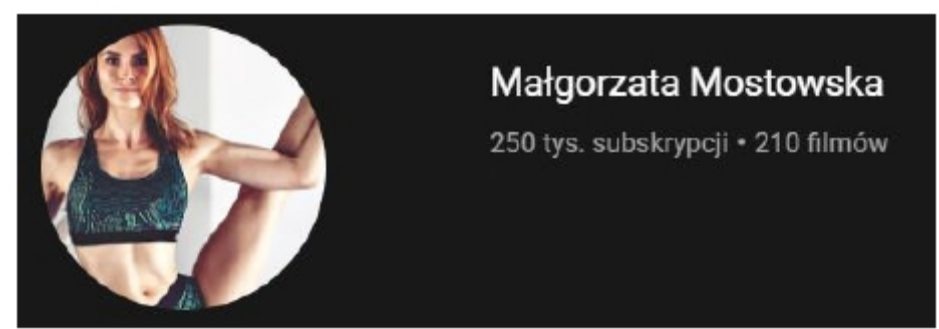

Source: https://www.youtube.com/, access: 09.07.2020

Statistics on the number of videos published by the described yogis and the number of subscribers are presented in the table (Tab. 5), and the functionality of the channels run on the YouTube website is presented in the following table (Tab. 6):

Tab. 5. Statistics of the discussed channels on YouTube

\begin{tabular}{|c|c|c|}
\hline CHANNEL NAME & NUMBER OF VIDEOS & $\begin{array}{c}\text { NUMBER OF SUBSCRIPTIONS } \\
\text { (IN THOUSANDS) }\end{array}$ \\
\hline Małgorzata Mostowska & 210 & 250 \\
\hline Simplife.pl & 41 & 12,1 \\
\hline Basiatworek.pl & 89 & 10,4 \\
\hline
\end{tabular}

Source: Own study based on https://www.youtube.com/, access: 09.07.2020 
Tab. 6. Evaluation of YouTube channels functionality

\begin{tabular}{|c|c|c|c|}
\hline TESTED FEATURE & $\begin{array}{c}\text { RATING +/- } \\
\text { (possibility } \\
\text { or lack thereof) }\end{array}$ & INTERPRETATION & SCORING \\
\hline 1. Payment & - & $\begin{array}{l}\text { No payment, access } \\
\text { free }\end{array}$ & 1 \\
\hline $\begin{array}{l}\text { 2. Live exercises } \\
\text { with a coach }\end{array}$ & - & $\begin{array}{l}\text { No possibility to exercise } \\
\text { on } \\
\text { live, exercises } \\
\text { yourself by following } \\
\text { application instructions }\end{array}$ & 0 \\
\hline $\begin{array}{l}\text { 3. Possibility } \\
\text { repeat the session }\end{array}$ & + & $\begin{array}{l}\text { Possibility } \\
\text { multiple plays } \\
\text { and repetitions }\end{array}$ & 1 \\
\hline $\begin{array}{l}\text { 4. Possibility } \\
\text { independent exercises }\end{array}$ & + & $\begin{array}{l}\text { Ability to work without } \\
\text { trainer }\end{array}$ & 1 \\
\hline $\begin{array}{l}\text { 5. High level } \\
\text { sessions and exercises, } \\
\text { adjusted to } \\
\text { individual } \\
\text { needs }\end{array}$ & - & $\begin{array}{l}\text { No individualization, } \\
\text { rather standard sessions }\end{array}$ & 0 \\
\hline $\begin{array}{l}\text { 6. Famous and } \\
\text { respected coaches }\end{array}$ & + & $\begin{array}{l}\text { Most of the coaches } \\
\text { has an i } \\
\text { presents sessions either } \\
\text { exercise }\end{array}$ & 1 \\
\hline $\begin{array}{l}\text { 7. Alternative for } \\
\text { classes in clubs }\end{array}$ & + & $\begin{array}{l}\text { Most clubs } \\
\text { only conducted classes } \\
\text { stationary, does not drive } \\
\text { regular sessions and } \\
\text { classes } \\
\text { according to graphic } \\
\text { designers }\end{array}$ & 0 \\
\hline $\begin{array}{l}\text { 8. Ease of use } \\
\text { and access, interface } \\
\text { user }\end{array}$ & + & $\begin{array}{l}\text { You just need access to } \\
\text { Internet, telephone or } \\
\text { computer and elementary } \\
\text { the ability to operate them }\end{array}$ & 1 \\
\hline $\begin{array}{l}\text { 9. The visual side } \\
\text { session and general } \\
\text { appearance }\end{array}$ & - & $\begin{array}{l}\text { All similar movies } \\
\text { to myself, no } \\
\text { honors and specials } \\
\text { visualization }\end{array}$ & 0 \\
\hline $\begin{array}{l}\text { 10. Distribution i } \\
\text { promotion for people } \\
\text { exposed to } \\
\text { coronovirus (e.g. } \\
\text { seniors) }\end{array}$ & + & $\begin{array}{l}\text { Rather low popularity } \\
\text { channel and popularity } \\
\text { classes among seniors, } \\
\text { but for the knowledgeable } \\
\text { to operate the computer } \\
\text { are } \\
\text { available }\end{array}$ & 1 \\
\hline Overall assessment & \multicolumn{2}{|l|}{ Total points: } & 6 \\
\hline
\end{tabular}

Source: Own study

\section{SWOT analysis of yoga practice online during the COVID-19 pandemic}

In addition to analyzing the functionality of using new forms of yoga, a SWOT analysis of online yoga practice during the COVID-19 pandemic was also carried out. The SWOT name is an abbreviation of the first letters of the words: strengths, weaknesses, opportunities and threats. It is one of the most popular methods of analysis used to determine the strengths and weaknesses of practicing yoga with the use of modern technologies, as well as its development opportunities and threats. The results of the analysis are presented in the table (Tab. 7): 
Tab. 7. SWOT analysis of yoga practice online

\begin{tabular}{|c|c|}
\hline STRENGTHS & WEAKNESSES \\
\hline $\begin{array}{l}\text { 1.no need to have } \\
\text { additional equipment, special } \\
\text { outfit } \\
\text { 2. the possibility of practicing yoga alone } \\
\text { with yoga apps, channels } \\
\text { on YouTube or broadcasts on } \\
\text { live } \\
\text { 3. possibility to practice at home } \\
\text { 4. No extra cost } \\
\text { 5. the positive effect of yoga on } \\
\text { reducing the feeling of stress i } \\
\text { anxiety } \\
\text { 6. a good influence of yoga on the system } \\
\text { immune so important to } \\
\text { keeping in good shape } \\
\text { during the COVID-19 pandemic } \\
\text { 7. the positive effect of yoga on the system } \\
\text { respiratory } \\
\text { 8. possibility to learn techniques } \\
\text { relaxation and breathing } \\
\text { 9. improving the concentration of } \\
\text { practitioners } \\
\text { 10. the acquisition of the ability to } \\
\text { concentrate } \\
\text { at the moment (being here and } \\
\text { now) }\end{array}$ & $\begin{array}{l}\text { 1. internet access needed } \\
\text { 2. the need for good service } \\
\text { modern technologies } \\
\text { (computer, smartphone) } \\
\text { 3. YouTube videos if available } \\
\text { the yoga sessions in the apps are ongoing } \\
\text { much shorter than standard } \\
\text { yoga practice offered in class } \\
\text { in clubs } \\
\text { 4.Little distribution and promotion } \\
\text { this type of activity among people } \\
\text { most vulnerable to } \\
\text { coronavirus (e.g. seniors) }\end{array}$ \\
\hline CHANCES & THREATS \\
\hline $\begin{array}{l}\text { 1. The spread of yoga through social } \\
\text { media } \\
\text { 2. thanks to possible free practice } \\
\text { more people online } \\
\text { practicing yoga } \\
\text { 3rd chance for offering clubs } \\
\text { online practice - new people can } \\
\text { see what is offered by } \\
\text { clubs with activities, and then (after } \\
\text { during the lockdown period they will start } \\
\text { practicing } \\
\text { in clubs stationary) } \\
\text { 4. universal access to } \\
\text { modern technologies } \\
\text { 5. The lockdown situation makes it no } \\
\text { yoga classes are organized } \\
\text { stationary therefore online yoga becomes } \\
\text { the only possibility for her } \\
\text { practicing }\end{array}$ & $\begin{array}{l}\text { 1. limited number of recipients - no } \\
\text { everyone likes to practice alone as well } \\
\text { older people may have a problem with } \\
\text { using new technologies } \\
\text { 2. working alone, without } \\
\text { a qualified yoga instructor } \\
\text { could be injured or injured } \\
\text { 3. threat to clubs - people who } \\
\text { start practicing online possible that } \\
\text { they will no longer feel the need } \\
\text { practicing stationary } \\
\text { 4. technological barriers } \\
\text { 5. development and return to other disciplines }\end{array}$ \\
\hline
\end{tabular}

11.07.2020 


\section{Conclusions and summary}

In the era of the coronavirus pandemic, everyone is exposed to more stress related to caring for their own health and the health of their loved ones, losing a job, increased responsibilities, more time spent at home, lack of exercise or omnipresent restrictions that prevent normal functioning in society. The situation is completely new, and this fact alone makes it difficult to learn to function in it. As is well known, physical activity promotes a good mood, improves mood and reduces the level of anxiety. Yoga can be treated as one of the forms of physical activity, but it also includes working with breathing and meditation. All these factors have a positive effect on the physical and mental condition of a person. The benefits of yoga for human health are countless and repeatedly presented and researched by many authors, which has been carefully collected and discussed through a broader analysis of sources and research on physical, physiological, psychological and spiritual benefits in the author's collective work (Pilarska 2020). In the coronavirus pandemic, however, particular importance can be attributed to the benefits and impact of yoga on well-being, stress reduction or even the treatment of depression, which have been thoroughly analyzed by many foreign researchers (Mc Call 2007, Franzblau et all. 2008, Bennett et all. 2008, Forbes et all. 2008, Woolery et all 2004, Da Silva et all. 2009, Harrigan 1991, Forfylow 2011, Khalsa et all., 2009, Telles et all. 2009, Smith et all. 2007 and others). No additional equipment is required to practice it, so it's also possibile to cultivate it at home.

The main problem of the presented research was to show what benefits and in what form can yoga practice bring about online in the era of the coronavirus pandemic? It can be admitted that this hypothesis has been confirmed based on the literature and internet sources. Yoga as a form of physical activity puts practitioners in a good mood, reduces the level of stress and feelings of anxiety resulting from the pandemic situation in the world. In addition, yoga practice, including relaxation and breathing exercises, introduces the participant to a state of well-being, and also maintains the immune and respiratory systems in good condition.

The most vulnerable to the virus are elderly, seriously ill and easily stressed people. This hypothesis was partially fulfilled because the forms of practicing yoga presented in this work online They are aimed at all people, but most of the tools for yoga practice are not readily available and widespread enough among seniors. People of this age often find it difficult to use modern technologies, such as smartphones or computers, and do not have accounts on social networking sites such as Facebook or Instagram.

Analysis of the functionality of individual forms of yoga online confirmed the hypothesis. On the Internet you can find many profiles running a fanpage on Facebook or Instagram, YouTube channels and applications for downloading to the phone, thanks to which practicing yoga online possible. Each person can choose the form of exercise that best suits them. Most of the internships offered online it's free, so regardless of your budget, you can afford yoga over the Internet. The weakness is that there are few practices conducted through live broadcasting and finding profiles that are on offer live it is time consuming. Due to the fact that the internships are aimed at all people, one cannot expect a lot of individualisation of the activities, as they are programmed to suit everyone who decides to join the practice. Working without an instructor or yoga teacher can also be dangerous if the person undertaking the practice does not know the basics of performing asanas, can perform them technically incorrectly, which may result in various kinds of injuries and injuries.

The SWOT analysis presented the strengths and weaknesses as well as the opportunities and threats of yoga practice online. A decisive opportunity for clubs offering such internships is that they can convince people interested in the internship to continue practicing yoga after reaching the clubs by purchasing a pass for classes at their club. The threat is the low dynamics of yoga classes, which many people do not like, so they choose other disciplines. Another threat are technological barriers, which mainly affect older people 
who are not able to use modern equipment such as computers or smartphones.

Yoga practice online during the coronavirus pandemic it has many benefits. Yoga is relaxing and healthy for people practicing it. In addition to helping to reduce stress levels, it has a positive effect on the condition of the immune and respiratory systems, which should be especially taken care of during a pandemic situation. In terms of functionality, the YouTube social network was the best, where you can find many videos promoting yoga practice. In addition to the variety of activities offered, the strength of the published videos is that the instructor explains exactly how to perform each position, which makes the practitioner feel as if he is practicing live with a yoga instructor. Access to collaborative practice channels is free and you can return to them multiple times and at any time.

\section{Bibliography:}

1. Bennett S. M., Weintraub A., Khalsa S. B., Initial evaluation of the Lifeforce Yoga Program as a therapeutic intervention for depression, International Journal of Yoga Therapy, 2008.

2. Da Silva T. L., Ravindran L. N., Ravindran A.V., Yoga in the treatment of mood and anxiety disorders: A review, Asian Journal of Psychiatry, 2009.

3. Domaradzki J., O skrytości zdrowia. O problemach z konceptualizacja pojęcia zdrowie/About the secret of health. On problems with the conceptualization of the concept of health, Hygeia Public Health, 2013.

4. Forbes B. i in., Yoga therapy in practice: Using integrative yoga therapeutics in the treatment of comorbid anxiety and depression, International Journal of Yoga Therapy, 2008.

5. Forfylow A. L., Integrating yoga with psychotherapy: A complementary treatment for anxiety and depression, Canadian Journal of Counselling and Psychotherapy, 2011.

6. Francina S., The New Yoga for Healthy Aging: Living Longer, Living Stronger and Loving Every Day, Hci, 2007.

7. Franzblau S. H., Echevarria S., Smith M., Van Cantfort T. E., A preliminaryinvestigation of the effects of giving testimony and learning yogic breathing techniques on battered women's feelings of depression, Journal of InterpersonalViolence, 2008.

8. Franzblau S. H., Echevarria S., Smith M., Van Cantfort T. E., A preliminary investigation of the effects of giving testimony and learning yogic breathing techniques on battered women's feelings of depression, Journal of Interpersonal Violence, 2008.

9. Grabara M., Juszczyk E., Szopa J, Ćwiczenia Hatha Jogi w profilaktyce i korekcji wad postawy ciała $i$ dzieci w wieku szkolnym, Proceedings, Opole, University of Technology, Opole 2006, str. 418-427.

10. Harrigan J. M., A component analysis of yoga: the effects of diaphragmatic breathing and stretching postures on anxiety, personality and somatic/behavioural complaints, Dissertation Abstracts International, 1991.

11. Khalsa S. B. S., Shorter S. M., Cope S., Wyshak G., Sklar E., Yoga ameliorates performance anxiety and mood disturbance in young professional musicians, Applied Psychophysiology and Biofeedback, 2009.

12. Kożuchowski K., Atmosfera, klimat, ekoklimat/Atmosphere, climate, ecoclimate, Wydawnictwo Naukowe PWN, Warszawa 1998.

13. Makvana S. M. i in., The International Journal of Indian Psychology, Volume 3, Issue 3, No. 2, 2016.

14. McCall T., Yoga as medicine. The Yogic Prescription for Health and Healing, Yoga Journal, New York 2007.

15. Pilarska Marta Korzyści zdrowotne wynikajace z praktyki jogi w czasach pandemii korona wirusal Health Benefits of Yoga Practice During Pandemic Times coronavirus, UMK Torun, manuscript 2020.

1. Sereda I. et all., The Impact of Yoga Practice on the Development of Flexibility Among the Female Student's Pedagogical Specialities in the Process of PhysicalTraining of Higher Educational Institutions w: International Journal of Applied Exercise Physiology, tom 9(1), EASSA 2020 (85-95).

2. Smith C., Hancock H., Mortimer J., Eckert K. A., A randomized comparative trial of yoga and relaxation to reduce stress and anxiety, Complementary Therapies in Medicine, 2007.

3. Szopa J., Lecznicze i fizjologiczne działanie YOGASANAS, Zeszyty Naukowe Wyższej Szkoły Zarządzania w Częstochowie, Częstochowa, 2000, nr 1, str. 47-49.

4. Telles S., Gaur V., Balkrishnai A., Effect of a yoga practice session and a yoga theory session on state anxiety, Perceptual and Motor Skills, 2009.

5. Woolery A., Myers H., Sternleib B., Zeltzeri L., A yoga intervention for Young adults with elevated symptoms of depression, Alternative therapies in health and medicine, 2004. 
6. Woynarowska B., Sokołowska M., Szkoła promujaca zdrowie. Doświadczenia dziesięciu lat / A health promoting school. Ten years of experience, Warszawa, 2000.

\section{Internet source:}

1. Google Play, https://play.google.com/store/search?q=praktyka\%20jogi\&c=apps\&gl=PL, https://play.google.com/store/apps (dostęp:28.05.2020 i 09.07.2020).

2. http://ipz.org.pl/uwwiedzowania-zdrowia/ (03.07.2020).

3. http://strefawolnejprasy.pl/chcesz-miec-dobre-samopoczucie-pomoga-w-tym-jony-ujemne/ (28.05.2020).

4. http://www.neurocentrum.pl/dcten/wp-content/uploads/markocka-maczka k5p.pdf (25.06.2020).

5. http://www.szpital-marciniak.wroclaw.pl/index.php?c=article\&id=9\&pdf=1 (24.05.2020).

6. https://gis.gov.pl/zdrowie/co-to-jest-zdrowy-styl-zycia-i-czemu-jest-wazny/ (dostęp: 24.05.2020).

7. https://kosmos.ptpk.org/index.php/Kosmos/article/view/986/969 (28.05.2020).

8. https://przewodnikduchowy.pl/a/korzysci-plynace-z-uprawiania-jogi.php (28.05.2020).

9. https://questus.pl/blog/analiza-swot-na-czym-polega-i-kiedy-ja-stosowac/ (dostęp: 11.07.2020).

10. https://synergiczni.pl/co-ma-stres-do-odpornosci-czyli-jak-nasze-emocje-wplywaja-na-cialo (28.05.2020).

11. https://www.hbrp.pl/b/jak-poprawic-koncentracje-i-byc-bardziej-efektywnym-poznaj-czterystrategie/PjUwg6OeF (28.05.2020).

12. https://www.swiatnauki.pl/8,488.html\# (dostęp: 28.05.2020).

13. https://www.umk.pl/wiadomosci/?id=26681 (02.04.2020).

14. https://www.who.int/about/who-we-are/constitution (24.05.2020).

15. https://yogamudra.pl/2015/06/24/wplyw-asan-jogi-yoga-asana/ (24.05.2020).

16. YouTube, https://www.youtube.com/channel/UCw-HC1NizWhlcFy7UT0kGcQ/about, https://www.youtube.com/channel/UCpqYY3zU3PbEPZ_7P-woiAw/about, https://www.youtube.com/user/kasieklxk/about (dostęp: 28.05.2020 i 09.07.2020). 